\title{
Automatic Tajweed Rules Recognition using k-Nearest Neighbour (k-NN)
}

\author{
Shafaf Ibrahim, Farah Afiqah Abdul Rahim, Zaaba Ahmad
}

\begin{abstract}
Tajweed refers to a pronunciation rule for Al-Quran recitation in Islam. It acts as guidance for Muslims in reciting the Al-Quran in a correct manner. Yet, Tajweed rules could be complicated as it consists of various types of laws. It could also be confusing, and difficult to remember particularly for the people who have less knowledge in Tajweed rules. Thus, a study on automatic tajweed rules recognition using image processing technique is proposed. The scope of this study is limited to Idgham laws only. Initially, the input image went through the pre-processing process which includes four sub-processes which are greyscale conversion, binary conversion, thinning and flip, and word segmentation. Next, six attributes of shape descriptor which are major axis length, minor axis length, eccentricity, filled area, solidity, and perimeter were extracted from each input image. A technique of $k$-Nearest Neighbour $(k-N N)$ is employed to recognize the two types of Idgham Laws which are Idgham Maal Ghunnah and Idgham Bila Ghunnah. The performance of the proposed study is evaluated to 180 testing images which returned $84.44 \%$ of classification accuracy. The outcome of this study is expected to recognize the Tajweed rules automatically and may assist the user on a proper recitation of Al-Quran.
\end{abstract}

Index Terms: Automatic recognition, $k$-Nearest Neighbour $(k-N N)$, regionprops, tajweed.

\section{INTRODUCTION}

Al-Quran is the holy book for Muslims revealed by God to Prophet Muhammad progressively over 23 years, through the angel Jibreel as the medium. It is generally meant as "That which is read" [1]. Recitation of the Al-Quran is controlled by many laws that contain in "Tajweed rules" which is referring to the right pronunciation of the Al-Quran [2]. Tajweed is an Arabic word that is derived from the root word 'jawwada' meaning to make well, make better and improve which refers to correct pronunciation during recitation [3].

The correct pronunciation of Al-Quran recitation had been ensured by Tajweed rules at a moderate speed, without changing the meaning [4]. It is compulsory for Muslims to read the Al-Quran in the correct way as it can change the actual meaning if there are any mistakes happen in Tajweed rules. Thus, reading Al-Quran in appropriate way is necessary in Islamic worship besides of prayers [5].

Presently, the problem of poor Al-Quran reading skills is always being an issue in the field of Islamic education [6]. It seems to be a serious problem that the Muslims should aware

Revised Version Manuscript Received on September 16, 2019.

Shafaf Ibrahim, Faculty of Computer and Mathematical Sciences, Universiti Teknologi MARA, Melaka Branch Jasin Campus, 77300 Merlimau, Melaka, Malaysia.

Farah Afiqah Abdul Rahim, Faculty of Computer and Mathematical Sciences, Universiti Teknologi MARA, Melaka Branch Jasin Campus, 77300 Merlimau, Melaka, Malaysia.

Zaaba Ahmad, Faculty of Computer and Mathematical Sciences, Universiti Teknologi MARA, Melaka Branch Jasin Campus, 35400 Tapah Road, Perak, Malaysia. as it is compulsory for them to recite the Quran properly by following the Tajweed rules. A problem that had contributed to Tajweed mistakes is a low frequency in reciting the Al-Quran lead to the Muslims to have misreading the Holy Book properly [7]. The incorrect recitation of certain Al-Quran's verses will cause to incorrect understanding [6]. So, it is obligatory for the Muslims to implement Tajweed rules whenever they recite any Al-Quran verses as to avoid wrong understanding and spreading a wrong message which contains in the Al-Quran.

The traditional learning session for Tajweed rules is called as a Talaqqi Musyafahah method [8]. However, the teacher's skills and their ability could be suspicious. There are possibilities of mishearing and prone to errors due to environmental disturbances such as noise and attention [4]. Additionally, learning hours are also limited.

The Tajweed rules cover nine areas of Nun Sakinah and Tanwin, rules of Mim Sakinah and rules of Mad Asli. Thus, it could be confusing, and difficult to remember particularly for the people who have less knowledge in Tajweed rules [6]. This supported by a survey conducted by [9] on testing tajweed knowledge which revealed astonishing result where only $16.3 \%$ of the participants have good knowledge in Tajweed rules, $37.5 \%$ of moderate, and $46.3 \%$ are still weak.

Based on the problem discussed, it was found that there is a need to improve the current way of learning Tajweed. A study of automatic recognition of Tajweed rules using image processing is proposed. The image processing technique is very effective and dependable day by day. It is very well known for its ability to significantly increase the interpretation accuracy of pictorial information [10]. Feature extraction techniques of shape were implemented to analyze the characteristics of the tajweed letters. Whereas, a k-Nearest Neighbour (k-NN) technique is used to recognize the two types of Idgham Laws which are Idgham Maal Ghunnah and Idgham Bila Ghunnah. The outcome is believed to automatically detect the Tajweed rules and may assist the user on proper recitation of Al-Quran.

\section{METHODOLOGY}

The aim of this study is to automatically recognize the tajweed rules using k-NN, and to evaluate the tajweed rules recognition performance. Fig. 1 depicts the proposed process flow of the tajweed rules recognition. 


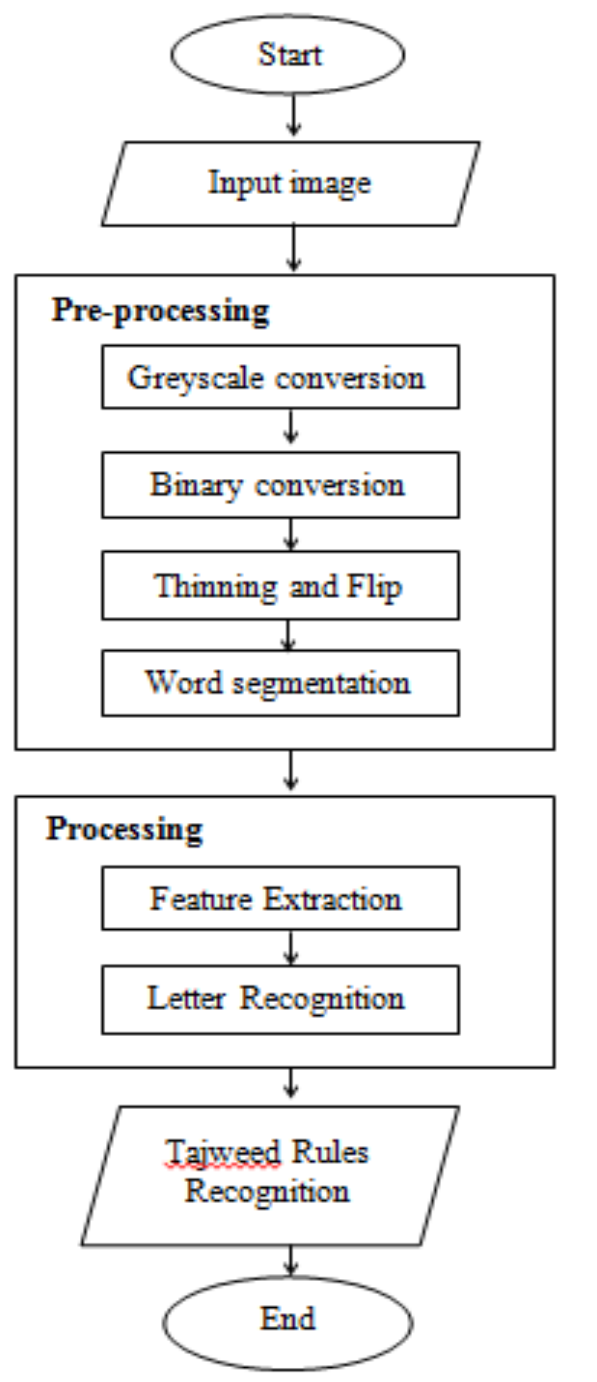

Fig. 1: Proposed process flow of tajweed rules recognition

The proposed process flow of tajweed rules recognition begins with the input image. The image will then go through the image pre-processing processes which comprise of four sub-processes which are greyscale conversion, binary conversion, thinning and flip, and word segmentation. Next, the processing consists of two sub-processes which are feature extraction and recognition. The feature extraction is used to extract the shape feature properties of the tajweed letters in the input image. Whereas, the recognition is used to recognize the tajweed letters and determine which tajweed rule that the image belongs to. After the image is recognized, the system will produce the final result which is the tajweed rule recognition.

\section{A. Input image}

This study is only focusing on Idgham Laws. There are two types of tajweed rules for Idgham Laws which are Idgham Maal Ghunnah and Idgham Bila Ghunnah. A total of hundred and eighty testing images were collected. There are four tajweed letters for Idgham Maal Ghunnah which are "Ya", "Wau", "Mim", and "Nun". Whereas, there are two types of tajweed letters for Idgham Bila Ghunnah which are "Ra" and "Lam". Table 1 tabulates the sample images for each type of tajweed letters and rules as mentioned.
Table 1: Sample images of tajweed rules

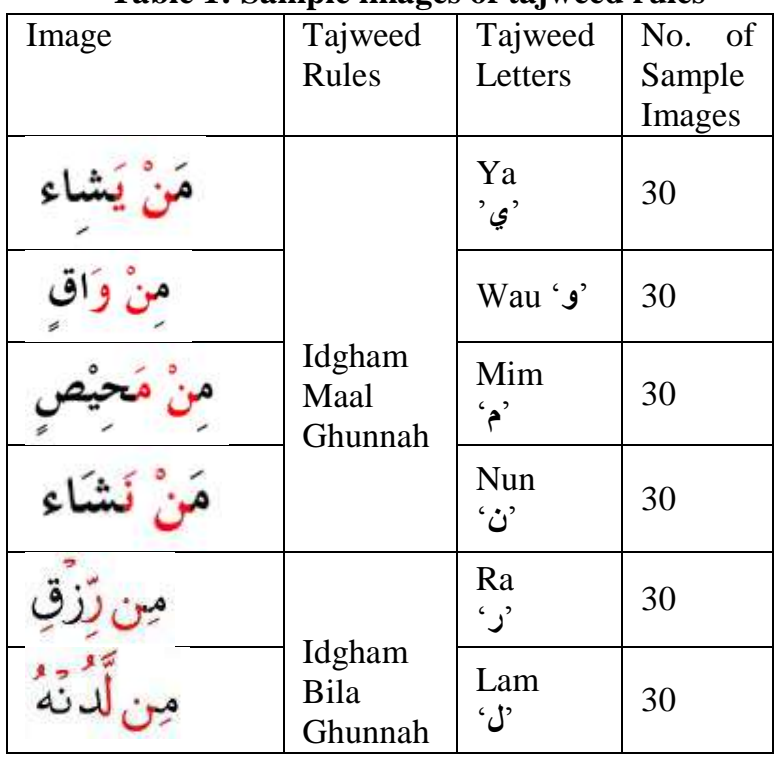

\section{B. Pre-processing}

Image pre-processing is a process where the input image is improved by suppresses the disfigurement or enhances some image features that are important for further processing [11]. The pre-processing includes four sub-processes which are greyscale conversion, binary conversion, thinning and flip, and word segmentation.

\section{Grayscale conversion}

Grayscale conversion is an approach to deal with a procedure and change the picture into dim or gray based color as the result [12]. Grayscale image simplifies and reduces computational requirements as colour can introduce unnecessary information that could raise the amount of training data required in achieving good performance. A grayscale image contains black and white colour only. Conversion of grayscale image from the Red Green Blue (RGB) image would carry out the intensity information of an image, compiled from black with the weakest intensity to white with the strongest intensity.

\section{Binary conversion}

In contrast, a binary image is a digital image that has only two possible values for each pixel either 1 or 0 [13]. The colour that is being used in binary image are black and white.

\section{Thinning and flip}

Next, the thinning is an erosion morphological operation which is used to shrink an image [14] and it only could be applied on a binary image. This method is chosen as it produced the best result in retrieving the characteristics of the input image as well as reducing the noise in the image. It is done by converting the image into inverse binary format beforehand as to preserve the feature of the image. The thinning is done by deleting the pixels inside the shape iteratively in order to shrink it without breaking it apart. Due to the condition of the Arabic word which is starting order from right to left, it is necessary to do the flip as the subsequent segmentation process will only perform its

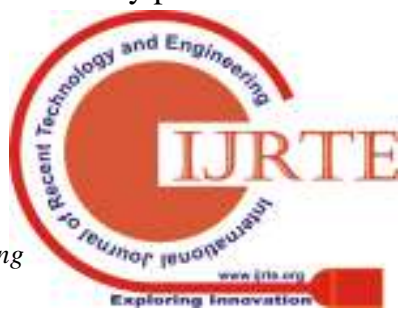


function accurately on an image from left to right order

\section{Word segmentation}

The word segmentation is performed to detect the space between the words and segment it into two different images. The histogram projection method is used to compute the sum of white pixels in every column which consequently construct the corresponding histogram. The vertical histogram for the image constructed and the white pixel which known as pixel 1 in each column be measured. By using the histogram, the columns which containing no white pixel will be labeled as pixel 0 , where the other column is replaced to pixel 1. Throughout the process, it will cut the 0 -pixel and remain the 1-pixel. The separated images are then being used as input in the subsequent process. Table 2 portrays the sample of outcomes for each process in pre-processing until the tajweed letter recognition.

\section{Processing}

The processing consists of two sub-processes which are feature extraction and recognition.

\section{Feature extraction}

The feature extraction is used to study the characteristics of each tajweed letter which consequently produce the summary table. The shape feature properties value of the segmented tajweed letter is extracted from the input image. The regionprops function is used to retrieve the feature value of the input image by computing the properties of each region within the image [15]. There are six shape feature properties extracted which are major axis length (MJAL), minor axis length (MNAL), eccentricity (ECC), filled area (FA), solidity (SLD) and perimeter (PRMT) of the desired area. Table 3 tabulates the summary table of the extracted feature properties. These values will then be compared with the same feature values of testing data before being recognized by the $\mathrm{k}-\mathrm{NN}$ algorithm.

\section{Recognition}

The recognition is done using the k-NN classifier. It is a mature algorithm and it is widely used in text classification [16]. The algorithm is simple, effective, easy interpretation, and low calculation time [17]. In this part of study, the k-NN is used to compare both data value into two categories of Idgham Maal Ghunnah or Idgham Bila Ghunnah. The Euclidean distance is used to find the difference between two distances. Fig. 2 depicts the process flow of k-NN using Euclidean distance. In (1) presents the calculation of two different distances.

$$
\sqrt{\sum_{i=1}^{k}\left(x_{i}-y_{i}\right)^{2}}
$$

(1)

$$
\begin{aligned}
& \text { where: } \\
& k=\text { number of neighbour } \\
& x=\text { value of plane } x \\
& y=\text { value of plane } y
\end{aligned}
$$

\begin{tabular}{|c|c|c|c|c|c|c|}
\hline \multirow{3}{*}{$\begin{array}{l}\text { Feature } \\
\text { Properties }\end{array}$} & \multicolumn{6}{|c|}{ Tajweed Type } \\
\hline & \multicolumn{4}{|c|}{ Idgham Maal Ghunnah } & \multicolumn{2}{|c|}{ Idgham Bila Ghunnah } \\
\hline & Ya'ي' & Wau 'و' & Mim 'P' & Nun 'ن' & $\mathrm{Ra}$ 'J' & Lam 'ل' \\
\hline MJAL & $1.15-123.85$ & $1.15-69.06$ & $5.187-59.8$ & $3.46-86.1$ & $2.56-52.58$ & $2.59-91.1$ \\
\hline MNAL & $1.15-28.67$ & $1.15-27.74$ & $2.75-24.1$ & $2.1-30.64$ & $1.16-17.78$ & $1.16-33.84$ \\
\hline ECC & $0-0.99$ & $0-0.99$ & $0.41-0.98$ & $0-1$ & $0.73-1$ & $0.73-0.99$ \\
\hline FA & $1-1126$ & $1-982$ & $13-474$ & $9-783$ & $3-322$ & $3-1176$ \\
\hline SLD & $0.314-1$ & $0.34-1$ & $0.31-1$ & $0.24-1$ & $0.25-1$ & $0.545-1$ \\
\hline PRMT & $0-275.75$ & $0-221.11$ & $10.29-18.24$ & $7.48-233.58$ & $3.1-114.1$ & $3.01-260.1$ \\
\hline
\end{tabular}

Table 2: Sample of outcomes for pre-processing and tajweed letter recognition

\begin{tabular}{|l|l|l|l|l|l|}
\hline Input Image & $\begin{array}{l}\text { Greyscale } \\
\text { Conversion }\end{array}$ & $\begin{array}{l}\text { Binary } \\
\text { Conversion }\end{array}$ & $\begin{array}{l}\text { Thinning, Inverse } \\
\text { Binary Conversion, and Flip }\end{array}$ & $\begin{array}{l}\text { Word } \\
\text { Segmentation }\end{array}$ \\
\hline Recognition \\
\hline Rime
\end{tabular}

Table 3: Summary table of feature properties 


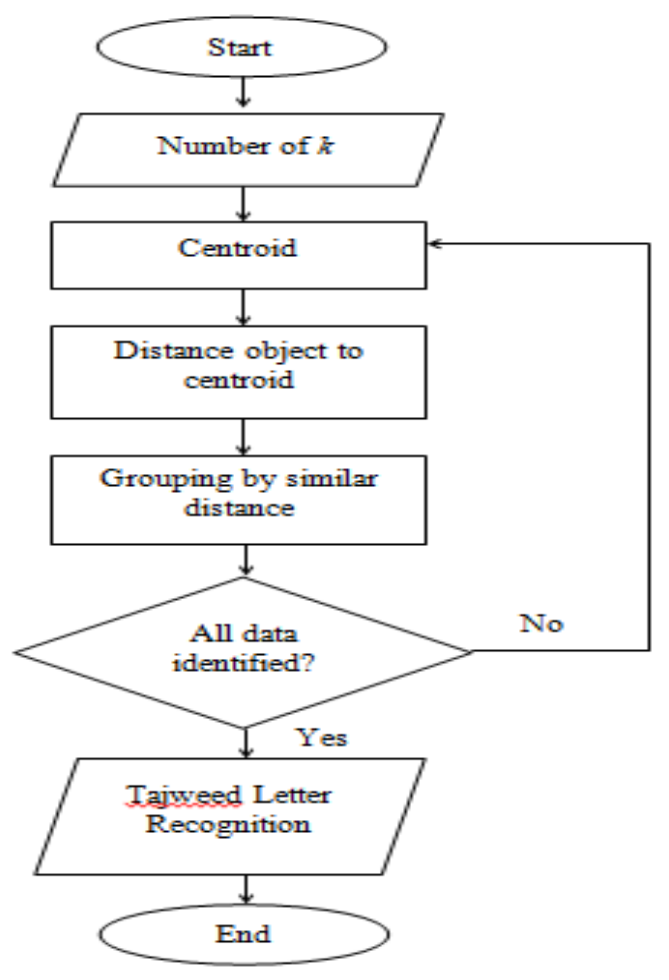

Fig. 2: Process flow of k-NN

Based on Fig. 2, the centroid is referred to the value of object of the extracted properties. Then, the distance is computed by using the Euclidean distance formula. The calculation halts when all data had been identified. The data is randomly divided into two groups which are training data and testing data. Table 4 tabulates the samples of the tajweed rules recognition of Idgham Law.

Table 4: Tajweed rules recognition

\begin{tabular}{|c|c|c|c|}
\hline Image No. & $\begin{array}{l}\text { Feature } \\
\text { Properties Value }\end{array}$ & Letter Recognition & Tajweed Rule \\
\hline 1 & $\begin{array}{l}\text { MJAL: } 26.99 \\
\text { MNAL: } 4.53 \\
\text { ECC: } 0.99 \\
\text { FA: } 90 \\
\text { SLD: } 0.84 \\
\text { PRMT: } 52.48\end{array}$ & $\begin{array}{l}\text { Ya } \\
\text { ' }\end{array}$ & \multirow{4}{*}{ Idgham Maal Ghunnah } \\
\hline 2 & $\begin{array}{l}\text { MJAL: } 8.94 \\
\text { MNAL: } 2.68 \\
\text { ECC: } 0.95 \\
\text { FA: } 13 \\
\text { SLD: } 0.72 \\
\text { PRMT: } 15.16 \\
\end{array}$ & Wau 'و' & \\
\hline 3 & $\begin{array}{l}\text { MJAL: } 59.8 \\
\text { MNAL: } 18.79 \\
\text { ECC: } 0.95 \\
\text { FA: } 286 \\
\text { SLD: } 0.38 \\
\text { PRMT: } 143.72\end{array}$ & $\begin{array}{l}\operatorname{Mim} \\
\text { '?' }\end{array}$ & \\
\hline 4 & $\begin{array}{l}\text { MJAL: } 56.31 \\
\text { MNAL: } 4.61 \\
\text { ECC: } 1 \\
\text { FA: } 195 \\
\text { SLD: } 1 \\
\text { PRMT: } 98.96 \\
\end{array}$ & $\begin{array}{l}\text { Nun } \\
\text { 'ن' }\end{array}$ & \\
\hline 5 & $\begin{array}{l}\text { MJAL: } 19.1 \\
\text { MNAL: } 3.48 \\
\text { ECC: } 0.98 \\
\text { FA: } 48 \\
\text { SLD: } 0.96 \\
\text { PRMT: } 37.08\end{array}$ & $\begin{array}{l}\mathrm{Ra} \\
\text { ' } \jmath\end{array}$ & \multirow{2}{*}{ Idgham Bila Ghunnah } \\
\hline 6 & $\begin{array}{l}\text { MJAL: } 6.33 \\
\text { MNAL: } 2.98 \\
\text { ECC: } 0.88 \\
\text { FA: } 10 \\
\text { SLD: } 0.71 \\
\text { PRMT: } 11.98\end{array}$ & $\begin{array}{l}\text { Lam } \\
\text { 'J' }\end{array}$ & \\
\hline
\end{tabular}




\section{Accuracy testing}

The performance of the tajweed rules recognition is evaluated using a truth table. It is performed by comparing the k-NN recognition result with the actual tajweed letters of the input image. Based on the truth table obtained, the recognition accuracy for each tajweed rules is calculated using (2):

$$
\% \text { of Accuracy }=\frac{\text { No.of TRUE Recognition Result }}{\text { Total No.of Testing Images }} \times 100 \%
$$

\section{RESULTS AND DISCUSSION}

Thirty testing images are tested for each tajweed rule. Table 5 displays some of the results plotted by the truth table from each tajweed rule.

Table 5: Samples of the truth table for tajweed rules recognition

\begin{tabular}{|c|c|c|c|c|}
\hline Image & $\begin{array}{l}\text { Actual } \\
\text { Letter }\end{array}$ & $\begin{array}{l}\text { k-NN } \\
\text { Letter } \\
\text { Recogniti } \\
\text { on }\end{array}$ & $\begin{array}{l}\text { k-NN } \\
\text { Tajweed } \\
\text { Rule } \\
\text { Result }\end{array}$ & $\begin{array}{l}\text { Accuracy } \\
\text { Result }\end{array}$ \\
\hline & $\begin{array}{l}\text { Ya } \\
\text { 'ي' }\end{array}$ & $\begin{array}{l}\text { Ya } \\
\text { 'ي' }\end{array}$ & $\begin{array}{l}\text { Idgham } \\
\text { Maal } \\
\text { Ghunnah }\end{array}$ & TRUE \\
\hline & $\begin{array}{l}\text { Wau } \\
\text { 'و' }\end{array}$ & $\begin{array}{l}\mathrm{Ra} \\
\text { 'J' }\end{array}$ & $\begin{array}{l}\text { Idgham } \\
\text { Bila } \\
\text { Ghunnah }\end{array}$ & FALSE \\
\hline & $\begin{array}{l}\text { Wau } \\
\text { ' } 9 \text { ' }\end{array}$ & Wau 'و' & $\begin{array}{l}\text { Idgham } \\
\text { Maal } \\
\text { Ghunnah }\end{array}$ & TRUE \\
\hline & $\begin{array}{l}\operatorname{Mim} \\
\text { 'p' }\end{array}$ & $\begin{array}{l}\operatorname{Mim} \\
\text { 'p' }\end{array}$ & $\begin{array}{l}\text { Idgham } \\
\text { Maal } \\
\text { Ghunnah }\end{array}$ & TRUE \\
\hline & $\begin{array}{l}\text { Nun } \\
\text { 'ن' }\end{array}$ & $\begin{array}{l}\text { Nun } \\
\text { 'ن' }\end{array}$ & $\begin{array}{l}\text { Idgham } \\
\text { Maal } \\
\text { Ghunnah }\end{array}$ & TRUE \\
\hline & $\begin{array}{l}\mathrm{Ra} \\
\text { ‘j' }\end{array}$ & $\begin{array}{l}\mathrm{Ra} \\
\text { ' } \mathrm{\prime}\end{array}$ & $\begin{array}{l}\text { Idgham } \\
\text { Bila } \\
\text { Ghunnah }\end{array}$ & TRUE \\
\hline siv & $\begin{array}{l}\mathrm{Ra} \\
\text { ‘j }\end{array}$ & Wau 'و' & $\begin{array}{l}\text { Idgham } \\
\text { Maal } \\
\text { Ghunnah }\end{array}$ & FALSE \\
\hline w & $\begin{array}{l}\text { Lam } \\
\text { 'J' }\end{array}$ & $\begin{array}{l}\text { Lam } \\
\text { 'J' }\end{array}$ & $\begin{array}{l}\text { Idgham } \\
\text { Bila } \\
\text { Ghunnah }\end{array}$ & TRUE \\
\hline
\end{tabular}

Subsequently, the accuracy performance of the tajweed rules

Table 6: Recognition accuracy result

\begin{tabular}{|c|c|c|c|c|}
\hline $\begin{array}{l}\text { Tajweed } \\
\text { Rules }\end{array}$ & Letter & $\begin{array}{l}\text { No. of } \\
\text { Testing } \\
\text { Images }\end{array}$ & $\begin{array}{l}\text { No. of TRUE } \\
\text { Recognition }\end{array}$ & $\begin{array}{l}\% \quad \text { of } \\
\text { Accuracy }\end{array}$ \\
\hline \multirow{4}{*}{$\begin{array}{l}\text { Idgham Maal } \\
\text { Ghunnah }\end{array}$} & Ya'ي' & 30 & 28 & 93.33 \\
\hline & $\begin{array}{l}\text { Wau } \\
\text { ‘g' }\end{array}$ & 30 & 22 & 73.33 \\
\hline & 'aim & 30 & 28 & 93.33 \\
\hline & $\begin{array}{l}\text { Nun } \\
\text { 'ن }\end{array}$ & 30 & 29 & 96.67 \\
\hline \multirow{2}{*}{$\begin{array}{l}\text { Idgham Bila } \\
\text { Ghunnah }\end{array}$} & $\mathrm{Ra}$ 'ر’ & 30 & 20 & 66.67 \\
\hline & $\begin{array}{l}\text { Lam } \\
\text { ‘J }\end{array}$ & 30 & 25 & 83.33 \\
\hline & & & Mean & 84.44 \\
\hline
\end{tabular}

From the calculation of accuracy, it is observed that the study produced the highest percentage of accuracy for "Nun" which is 96.67\%. Both "Ya" and "Mim" also returned a good percentage of accuracy which is $93.33 \%$. The "Lam" is also cannot be underestimated which produced $83.33 \%$ of accuracy. However, recognition is demonstrated in Table 6.

"Waw" and "Ra" returned a moderate percentage of accuracy which is $73.33 \%$ and $66.67 \%$ respectively. It may cause by the confusion in recognizing the shapes between those two letters which seems slightly similar. The overall mean percentage of accuracy is found to produce a very good percentage of accuracy which is $84.44 \%$.

\section{CONCLUSION}

This paper proposed a study on automatic tajweed rules recognition using image processing technique. The study is focusing on the recognition of tajweed rules for Idgham Laws only which are Idgham Maal Ghunnah and Idgham Bila Ghunnah. Feature extraction techniques of shape were implemented to analyze the characteristics of the tajweed letters. In another note, a k-Nearest Neighbour (k-NN) technique is used to recognize four types of letters for Idgham Maal Ghunnah which are "Ya", "Wau", "Mim", and "Nun", and two types of letters for Idgham Bila Ghunnah which are "Ra" and "Lam". The application to a variety of testing images has been successful. The performance of the tajweed rules recognition is evaluated using a truth table. The overall mean percentage of accuracy demonstrated a very good percentage of accuracy which is $84.44 \%$. It can therefore be concluded that the proposed application of image processing techniques for tajweed rules recognition is found to be successful. Yet, implementation and incorporation of the current feature extraction and recognition techniques such as deep convolutional neural network are recommended.

\section{ACKNOWLEDGMENT}

The research was supported by Ministry of Education Malaysia (MoE), and Universiti Teknologi MARA through the Fundamental Research Grant Scheme (FRGS) (600-IRMI/FRGS 5/3 (215/2019)).

\section{REFERENCES}

1. T. Haider, "Universality in the Message of Quran," Journal of South Asian Studies, 4(2), 2016, pp. 61-65.

2. Y. O. M. Elhadj, M. A. Aoun-allah, I. Alsughaiyer, and A. Alansari, "A new scientific formulation of Tajweed rules for e-learning of Quran Phonological Rules," E-Learning Engineering, on-Job Training and Interactive Teaching, 12, 2012, pp. 197-214.

3. A. Alfaries, M. Albahlal, M. Almazrua, and A. Almazrua, "A rule based annotation system to extract Tajweed rules from Quran," Taibah University International Conference on Advances in Information Technology for the Holy Quran and Its Sciences, 2013, pp. 281-286.

4. I. Ahsiah, N. M. Noor, and M. Y. I. Idris, "Tajweed checking system to support recitation," International Conference on Advanced Computer Science and Information Systems, 2013, pp. 189-193.

5. N. J. Ibrahim, M. Y. I. Idris, M. Y. Z. Mohd Yusoff, and A. Anuar, "The problems, issues and future challenges of automatic speech recognition for Quranic verse recitation: A review," Al-Bayan: Journal of Qur'an and Hadith Studies, 13, 2015, pp. 168-196.

6. S. S. Shahbudin and M. A. Zailaini, "Analysis of Tajweed errors in Quranic recitation," Procedia - Social and Behavioral Sciences, 103, 2013, pp. 136-145.

7. N. Kamarudin and S. Salam, "Tajweed understanding among Malaysian Muslim (a preliminary findings)," International Conference on Mobile Learning, Application and Services, 2012, pp. 1-4.

8. A. H. Tamuri, A. M. Ismail, A. H. M. Noor, and M. I. H. Pisol, "Penilaian guru terhadap pelaksanaan model-model 
Tilawah al-Quran Program j-QAF," International Journal of Islamic Thought, 3, 2013, pp. 1-17.

9. M. Jemali, A. H. Tamuri, and A. Hashim, "Kaedah pengajaran Al-Quran Sekolah Menengah Kebangsaan di Negeri Perak," International Journal of Islamic Studies and Arabic Language Education, 1(1), 2014, pp. 35-44.

10. O. Aljohani and A. Siada, "Application of digital image processing to detect transformer bushing faults and oil degradation using FRA Polar Plot Signature," IEEE Transactions on Dielectrics and Electrical Insulation, 24(1), 2017, pp. 428-436.

11. C. Laofor and V. Peansupap, "Automation in Construction Defect detection and quantification system to support subjective visual quality inspection via a digital image processing: A tiling work case study," Automation in Construction, 24, 2012, pp. 160-174.

12. S. A. Haney, D. G. Bowman, A. Chakravarty, A. Davies, and C. Shamu, An Introduction to High Content Screening: Imaging Technology, Assay Development, and Data Analysis in Biology and Drug Discovery. New Jersey: John Wiley and Sons, 2015.

13. A. S. R. Sinaga, "Binary image object identification using fuzzy logic and labeling breadh-first," Journal of Telematics and Informatics, 6(4), 2018.

14. R. M. Thanki and A. M. Kothari, "Morphological image processing," in Digital Image Processing using SCILAB, Cham: Springer, 2019, pp. 99-113.

15. C. Shanmugam and E. C. Sekaran, "IRT image segmentation and enhancement using FCM-MALO approach," Infrared Physics and Technology, 97, 2019, pp. 187-196.

16. J. Liu, T. Jin, K. Pan, Y. Yang, Y. Wu, and X. Wang, "An improved KNN text classification algorithm based on Simhash," IEEE 16th International Conference on Cognitive Informatics and Cognitive Computing, 2017, pp. 92-95.

17. A. Moldagulova and R. Sulaiman, "Using KNN algorithm for classification of textual documents," International Conference on Information Technology, 2017, pp. 665-671. 